\title{
ANALISIS KEMAMPUAN KOMUNIKASI MATEMATIS SISWA PADA PEMBELAJARAN DARING MATERI EKSPONENSIAL
}

\author{
Refiesta Ratu Anderha ${ }^{1}$, Sugama Maskar ${ }^{2}$ \\ Universitas Teknokrat Indonesia ${ }^{1,2}$ \\ refiestaanderha15@gmail.com
}

\begin{tabular}{lll}
\hline Received: 19 November 2020 & Accepted: 26 November 2020 & Published : 26 Desember 2020 \\
\hline
\end{tabular}

\begin{abstract}
This study aims to determine and analyze the mathematical communication skills of high school students on exponential material. The sample in this study were 5 students of class X MIPA 5 SMA Negeri 5 Bandarlampung. The type of research used is descriptive qualitative. The research instrument was a test of mathematical communication skills in the form of 5 essay items and an explanation video. The results of tests that have been carried out on several mathematical communication questions show good results. It can be seen from the percentage of the score per item, namely question number 1 obtained a percentage of 50\% for indicators in explaining ideas, situations orally or in writing in their own language. Question number 2 with the acquisition of a percentage of $85 \%$ for indicators of solving problems along with the rules used. Problem number 3 got a percentage of $85 \%$ and question number 4 got a percentage of $70 \%$ for the indicator of solving a problem based on mathematical concepts. Question number 5 obtained a percentage of $25 \%$ for indicators of finding and solving mathematical models in ordinary language. So it can be concluded that the level of mathematical communication skills of high school students is quite good and is classified as medium to very high.
\end{abstract}

Keywords: Ability, Mathematical Communication, Exponential.

\begin{abstract}
Abstrak
Penelitian ini memiliki tujuan untuk mengetahui serta menganalisis kemampuan komunikasi matematis siswa SMA pada materi Eksponensial. Sampel dalam penelitian ini adalah 5 orang siswa kelas X MIPA 5 SMA Negeri 5 Bandarlampung. Adapun jenis penelitian yang digunakan adalah deksriptif kualitatif. Instrumen penelitian adalah soal tes kemampuan komunikasi matematis berupa 5 butir soal essay serta video penjelasan. Hasil tes yang telah dilaksanakan pada beberapa soal komunikasi matematis menunjukan hasil yang baik. Terlihat dari presentase skor per butir soal yaitu soal nomor 1 diperoleh persentase 50\% untuk indikator dalam menjelaskan ide, situasi secara lisan atau tulisan dengan bahasa sendiri. Soal nomor 2 dengan perolehan persentase $85 \%$ untuk indikator menyelesaikan masalah disertai aturan yang digunakan. Soal nomor 3 diperoleh persentase $85 \%$ dan soal nomor 4 memperoleh persentase $70 \%$ untuk indikator menyelesaikan suatu masalah berdasarkan konsep matematika. Soal nomor 5 diperoleh persentase $25 \%$ untuk indikator mencari dan menyelesaikan model matematika ke dalam bahasa biasa.Maka dapat disimpulkan bahwa tingkat kemampuan komunikasi matematis siswa SMA sudah cukup baik dan tergolong sedang ke sangat tinggi.
\end{abstract}

Kata Kunci: Komunikasi Matematis, Pembelajaran Daring, Eksponensial.

\section{Sitasi artikel ini:}

Anderha, R. \& Maskar, S. (2020). Analisis Kemampuan Komunikasi Matematis Siswa pada Pembelajaran Daring Materi Eksponensial. Jurnal Ilmiah Matematika Realistik, 1(2), 1-7.

\section{PENDAHULUAN}

Perkembangan teknologi informasi pada era revolusi industir 4.0 yang betumpu pada otomatisasi menggunakan internet dan robotik. Hal tersebut juga memberikan pengaruh pada proses pembelajaran di dunia pendidikan, terutama pada pembelajaran daring (Maskar \& Anderha, 2019). Pendidikan merupakan salah satu 
hal yang perlu dimiliki oleh setiap individu, karena dengan pendidikan manusia dapat berkembang dan mempunyai arah serta tujuan atas dirinya dalam bertindak maupun berfikir. Untuk dapat bertahan hidup setiap individu perlu dibekali pengetahuan agar memiliki kecakapan baik berupa keterampilan yang menghasilkan sebuah produk atau keterampilan dalam menghadapi masalah yang terjadi dalam masyarakat (Dewi \& Septa, 2019). Pada prosesnya pendidikan pasti menemui pembelajaran yang membahas tentang matematika. Matematika adalah ilmu yang berperan penting dalam dunia pendidikan. Selain sebagai Queen of Science matematika juga dikatakan sebagai cabang ilmu pengetahuan yang menunjang ilmu pengetahuan lainnya serta berkaitan dengan kehidupan sehari-hari (Chotimah, dkk, 2018). Hal ini menunjukkan bahwa matematika adalah mata pelajaran yang wajib dipelajari dari awal siswa mengenal apa itu belajar. Namun, pandangan siswa mengenai matematika sebagai pelajaran yang sulit masih belum bisa dihilangkan, hal ini karena dalam matematika banyak terdapat teorema, rumus, dan definisi yang menyebabkan siswa enggan, malas, malu, dan takut dalam mengungkapkan ide maupun menyelesaikan soal-soal latihan yang diberikan di depan kelas (Ulfa, 2019). Akan tetapi pernyataan ini ditentang oleh Puspaningtyas (2019), dikatakan bahwa pelajaran matematika tidak melulu tentang angka, tetapi jauh lebih dalam dari itu. Banyak kemampuan yang bisa dikembangkan dari pembelajaran matematika, antara lain penyelesaian masalah, komunikasi matematis, dan koneksi matematis. Komunikasi dan koneksi matematis dapat diperoleh dengan menggunakan pendekatan budaya melalui matematika realistik. Hal tersebut membuat peserta didik lebih mudah memahami penerapan dan manfaat matematika dalam kehidupan sehari-hari (Maskar, 2018).

Matematika sebagai cabang ilmu tentunya sangat diperlukan untuk berkomunikasi secara lisan maupun tulisan akan lebih mudah untuk diketahui dan dipahami oleh orang lain. Seperti apa yang dikemukakan Cockroft dalam Choridah (2013),

'We believe that all these percepcions of the usefulness of mathematics arise from the fact that mathematics provides a means of communication which is powerful, concise, and unambiguous.'

Pernyataan ini menunjukkan tentang perlunya para siswa belajar matematika dengan alasan bahwa matematika merupakan alat komunikasi yang sangat kuat, teliti, dan tidak membingungkan. Maka dari itu pembelajaran matematika perlu dikembangkan demi tercapainya tujuan pembelajaran yang diinginkan salah satunya adalah kemampuan komunikasi matematis yang ada pada siswa.

Kemampuan komunikasi dalam pembelajaran sangat penting untuk dimiliki siswa guna menunjang aktivitas di dalam dan di luar kelas. Terutama saat kegiatan belajar mengajar materi matematika siswa/i harus memiliki kemampuan komunikasi matematis untuk memecahkan permasalahan dan juga menyampaikan ide atau gagasan. Beberapa penulis mendefinisikan istilah komunikasi dengan cara berbeda, NCTM atau National Council of Teacher Mathematics dalam Hendriana, dkk. (2017) menyatakan bahwa komunikasi matematis adalah satu kompetensi dasar matematis yang esensial dari matematika dan pendidikan matematika. Tanpa komunikasi yang baik, maka perkembangan matematika akan terhambat. Komunikasi matematis perlu dikembangkan lagi di dalam pembelajaran matematika. Selain berguna agar siswa/i mampu mengemukakan suatu gagasan atau ide juga mampu membentuk siswa/i dalam menjelaskan suatu model matematika ke bahasa biasa. Menurut NCTM atau National Council of Teacher Mathematics (2000) terdapat lima kompetensi dalam pembelajaran matematika, yaitu: pemecahan masalah matematik, komunikasi matematik, penalaran matematik, koneksi matematik, dan representasi matematik. Salah satu hal yang harus diperhatikan dari kelima kompetensi itu yaitu kemampuan komunikasi. Seperti halnya yang diungkapkan Ruseffendi (2006), dalam matematika penggunaan simbol dan istilah di dalamnya menjadikan karakteristik bahwa matematika itu sebagai bahasa yang memang perlu kita pahami dan sebelumnya telah disepakati. Selain lima kompetensi di atas untuk dapat mengembangkan kemampuan tersebut perlu dikaji apa dan bagaimana kemampuan komunikasi matematis yang dimaksud secara teoritis (Armiati, 2009). Kemampuan komunikasi matematis menjadi salah satu tujuan penting dari setiap materi yang disampaikan oleh guru, karena guru merupakan pembimbing siswa untuk mencapai konsep yang diharapkan.

Hal ini sesuai dengan pendapat dari Hujodo (2003) yang menyatakan "pengetahuan yang disampaikan oleh guru dapat dipahami oleh peserta didik, itulah tujuan dari mengajar dari mengajar". Pernyataan ini didukung oleh Syarifah (2017), bahwa pendidikan yang baik dapat membawa siswa kepada tujuan yang ingin dicapai yaitu agar bahan yang disampaikan dipahami sepenuhnya oleh siswa. Pentingnya pemilikan kemampuan komunikasi matematis antara lain dikemukan Baroody dalam Hendriana \& Soemarmo (2014) dengan rasional a) matematika adalah bahasa esensial yang tidak hanya sebagai alat berpikir, menemukan rumus menyelesaikan masalah, atau menyimpulkan saja, namun matematika juga memiliki nilai yang tak terbatas untuk menyatakan beragam idea secara jelas, teliti dan tepat; b) matematika dan belajar matematika adalah jantungnya kegiatan sosial manusia, misalnya dalam pembelajaran matematika interaksi antara guru dan siswa, antara siswa dan 
siswa, antara bahan pembelajaran matematika dan siswa adalah faktor- faktor dalam memajukan potensi siswa. Adapun indikator pada kemampuan komunikasi yang dikemukan oleh Soemarmo dalam Hendriana, dkk. (2017) antara lain:

1. Menyatakan benda-benda nyata, situasi dan peristiwa sehari-hari ke dalam bentuk model matematika (gambar, tabel, diagram, grafik, aljabar),

2. Menjelaskan ide dan model matematika (gambar, tabel, diagram, grafik, aljabar) ke dalam bahasa biasa.

3. Menjelaskan serta membuat pertanyaan matematika yang dipelajari

4. Mendengar, menulis kemudian berdiskusi tentang matematika

5. Membaca dengan pemahaman suatu prestasi tertulis

6. Membuat konjektur, menyusun argumen, merumuskan definisi dan generalisasi.

7. Menjelaskan dan membuat pertanyaan tentang matematika yang dipelajari.

Selain dua aspek pentingnya kemampuan komunikasi matematis siswa, indikator kemampuan komunikasi pun harus sudah dipahami oleh siswa dalam menyelesaikan permasalahan pada pembelajaran matematika. Menurut Bernard (2015) indikator kemampuan komunikasi dapat menjadi acuan guru dalam mengembangkan kemampuan siswa untuk mengkomunikasikan hasil yang berhubungan dengan masalah matematika kedalam bentuk atau hal berupa gambar, grafik, dan simbol-simbol matematika yang dijadikan sebagai alat dalam menyelesaikan permasalahan. Berdasarkan uraian diatas, maka permasalahan dan tujuan dari penelitian yang akan dibahas adalah analisis kemampuan komunikasi matematis siswa pada pembelajaran daring materi eksponensial.

\section{METODE PENELITIAN}

Metode penelitian yang digunakan adalah metode kualitatif dan pendekatan kuantitatif. Populasi dalam penelitian ini adalah siswa/I SMA Negeri 5 Bandarlampung. Teknik pengambilan sampel yang digunakan adalah Stratified Random Sampling, yaitu 5 orang siswa kelas X MIPA 5 di SMA Negeri 5 Bandarlampung. Teknik pengambilan sampel ini digunakan karena melihat dari tingkatan hasil penilaian evaluasi selama proses pembelajaran daring materi eksponensial. Adapun 3ndica pengumpulan data dalam penelitian ini adalah tes kemampuan komunikasi matematis. Instrumen penelitian berupa soal yang telah dibuat sesuai dengan 3ndicator kemampuan komunikasi matematis siswa pokok bahasan eksponensial. Untuk mengetahui persentase kesalahankesalahan setiap 3ndicator dalam menyelesaikan soal pokok bahasan ekponensial maka digunakan rumus sebagai berikut:

$$
P=\frac{\text { Total } \Sigma s}{\text { Total } \Sigma x \times S M} \times 100 \%
$$

Keterangan :

$$
\begin{array}{ll}
P & : \text { Persentase yang diperoleh siswa } \\
\Sigma S & : \text { Total skor butir soal } \\
\Sigma x & : \text { Jumlah sampel } \\
S M & : \text { Skor maksimal }
\end{array}
$$

Untuk mengetahui tinggi rendahnya persentase kemampuan pemahaman matematis siswa maka peneliti menggunakan acuan sebagai berikut:

Tabel 1. Persentase Kemampuan Siswa

\begin{tabular}{ll}
\hline Persentase $(\%)$ & Kriteria \\
\hline $0 \leq P<20$ & Sangat Rendah \\
\hline $20 \leq P<40$ & Rendah \\
\hline $40 \leq P<60$ & Sedang \\
\hline $60 \leq P<80$ & Tinggi \\
\hline $80 \leq P<100$ & Sangat Tinggi \\
\hline
\end{tabular}

Arikunto (2009) 
Tabel 2. Pedoman Penskoran Kemampuan Komunikasi Matematis

\begin{tabular}{|c|l|}
\hline Skor & \multicolumn{1}{|c|}{ Kriteria } \\
\hline 4 & $\begin{array}{l}\text { Respon lengkap dan jelas, tidak ragu - ragu, diagram lengkap, komunikasi efisien, sajian logis, disertai } \\
\text { dengan contoh }\end{array}$ \\
\hline 3 & $\begin{array}{l}\text { Respon benar, lengkap dan jelas, diagram lengkap, komunikasi efisien, dan sajian lengkap tapi tidak } \\
\text { disertai contoh }\end{array}$ \\
\hline 2 & $\begin{array}{l}\text { Respon benar, lengkap dan jelas, diagram lengkap, komunikasi dan sajian kurang lengkap dan tidak } \\
\text { disertai contoh }\end{array}$ \\
\hline 1 & $\begin{array}{l}\text { Respon benar tapi kurang lengkap/jelas, diagram, komunikasi dan sajian kurang lengkap, tidak disertai } \\
\text { contoh }\end{array}$ \\
\hline 0 & Respon dan komunikasi tidak efisien, misinterpretasi (lembar jawaban kosong/tidak ada jawaban) \\
\hline
\end{tabular}

\section{Teknik Analisis Data}

Analisis data adalah proses menyusun secara sistematis data hasil wawancara, observasi dan dokumentasi dengan cara memilih mana yang penting serta mana yang perlu dipelajari untuk membuat kesimpulan yang mudah dipahami (Sugiyono, 2016). Teknik analisis data yang digunakan pada penelitian ini adalah analisis kualitatif berdasarkanMiles dan Hubberman, yaitu pengumpulan data, reduksi data, penyajian data, dan penarikan kesimpulan. Langkah-langkah tersebut dapat dilihat secara ringkas dalam bagan di bawah ini.

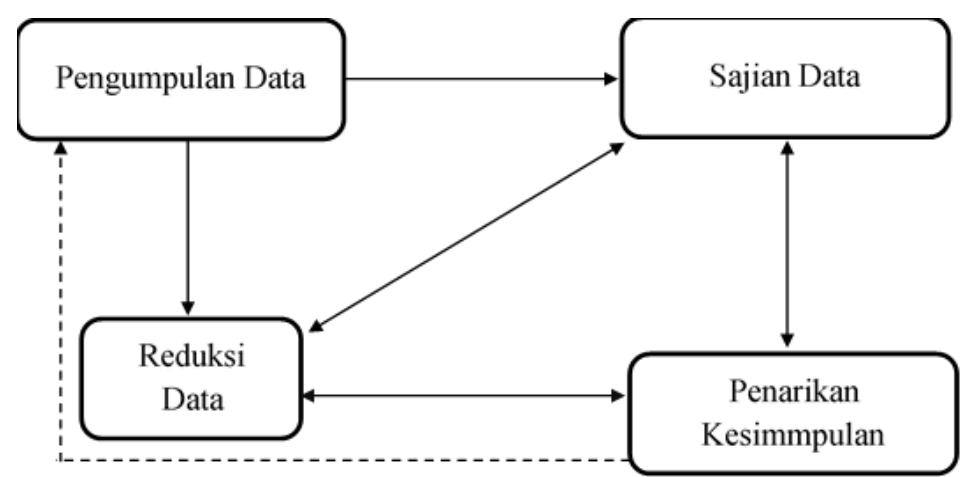

Gambar 1. Teknik Analisis Data Kualitatif

a. Reduksi Data

Penyederhanaan data yang dilakukan dengan merubah data mentah menjadi informasi yang bermakna sehingga mempermudah dalam penarikan kesimpulan. Data mentah dalam penelitian ini yaitu hasil pengerjaan soal yang dilakukan oleh sampel.

b. Penyajian Data

Penyajian data adalah sekumpula informasi yang digunakan untuk membantu penarikan kesimpulan. Di penelitian ini, data disajikan menggunakan tabel.

c. Penarikan Kesimpulan

Penarikan kesimpulan merupakan tahap akhir dalam analisis data. Data yang disusun dibandingkan antara satu dengan yang lain untuk ditarik kesimpulan

\section{HASIL DAN PEMBAHASAN}

Data hasil jawaban soal tes kemampuan pemahaman matematis dan kemampuan komunikasi matematis dilakukan sebuah analisis untuk memperoleh gambaran seberapa besar siswa menguasai kemampuan pemahaman matematis dan kemampuan komunikasi matematis. Tiap soal memiliki satu atau dua indikator komunikasi matematis. Hal ini dilakukan agar sesuai dengan jenjang berpikir yang berkembang pada diri setiap siswa.Vui (2007) menjenjangkan soal matematika berdasarkan tingkat pemikiran siswa dalam empat tingkatan, dari terendah sampai tertinggi yaitu (1) mengeksplorasi dan mengingat fakta, prinsip, dan prosedur, (2) mempraktikan latihan dan keterampilan, (3) memecahkan masalah, dan (4) investigasi. 
Jurnal Ilmiah Matematika Realistik (JI-MR), Vol: 1, No: 2, 1-7

Tabel 3. Persentase Kemampuan Komunikasi Matematis

\begin{tabular}{|c|c|c|c|c|c|}
\hline \multirow{2}{*}{ Kode Siswa } & \multicolumn{5}{|c|}{ Skor Soal } \\
\cline { 2 - 6 } & No. 1 & No. 2 & No. 3 & No. 4 & No. 5 \\
\hline $\mathrm{X} 1$ & 3 & 4 & 4 & 4 & 2 \\
\hline $\mathrm{X} 2$ & 2 & 1 & 1 & 0 & 0 \\
\hline $\mathrm{X} 3$ & 3 & 4 & 4 & 4 & 1 \\
\hline $\mathrm{X} 4$ & 1 & 4 & 4 & 3 & 1 \\
\hline $\mathrm{X} 5$ & 1 & 4 & 4 & 3 & 1 \\
\hline$\Sigma S$ & 10 & 17 & 17 & 14 & 5 \\
\hline$\sum x \times S M$ & 20 & 20 & 20 & 20 & 20 \\
\hline Persentase & $50 \%$ & $85 \%$ & $85 \%$ & $70 \%$ & $25 \%$ \\
\hline
\end{tabular}

Berdasarkan tabel 3 dapat dilihat perolehan persentase terhadap kemampuan komunikasi matematis siswa. Untuk soal nomor 1 diperoleh persentase 50\% untuk indikator dalam menjelaskan ide, situasi secara lisan atau tulisan dengan bahasa sendiri serta menyusun argumen, merumuskan definisi dan generalisasi. Soal nomor 2 dengan perolehan persentase $85 \%$ untuk indikator menyelesaikan masalah disertai aturan yang digunakan. Soal nomor 3 diperoleh persentase $85 \%$ dan soal no.4 memperoleh persentase $70 \%$ untuk indikator menyelesaikan suatu masalah berdasarkan konsep matematika. Soal nomor 5 diperoleh persentase $25 \%$ untuk indikator mencari dan menyelesaikan model matematika ke dalam bahasa biasa.

Berikut ini adalah tampilan hasil jawaban siswa yang masih belum tepat dan masih mengalami kesalahan.

1. Manakah pernyataan di bawah ini yang bukan termasuk fungsi eksponen dan berikan penjelasannya!
a. $y=f(x)=1,5^{x}$
b. $y=f(x)=x^{x}$
c. $y=f(x)=e^{x}$

Gambar 2. Soal Nomor 1

Pada soal nomor 1 siswa di minta untuk menjelaskan bentuk matematika ke dalam argumen sendiri berdasarkan konsep dan bentuk fungsi eksponensial. Di bawah ini adalah hasil pekerjaan siswa yang masih mengalami kesalahan dalam menjawab persoalan.

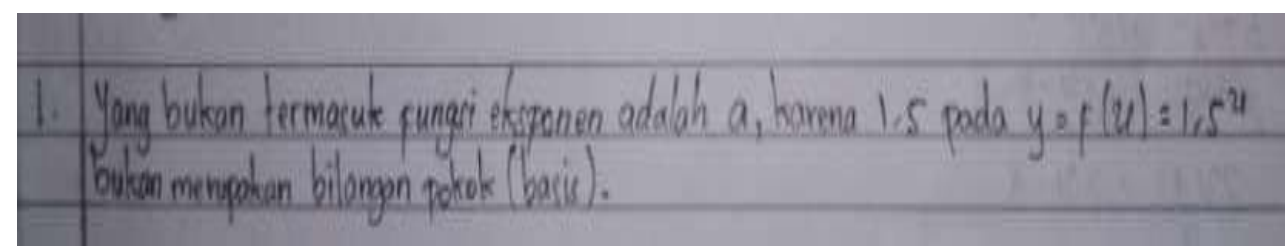

Gambar 3. Jawaban soal nomor 1 siswa X2

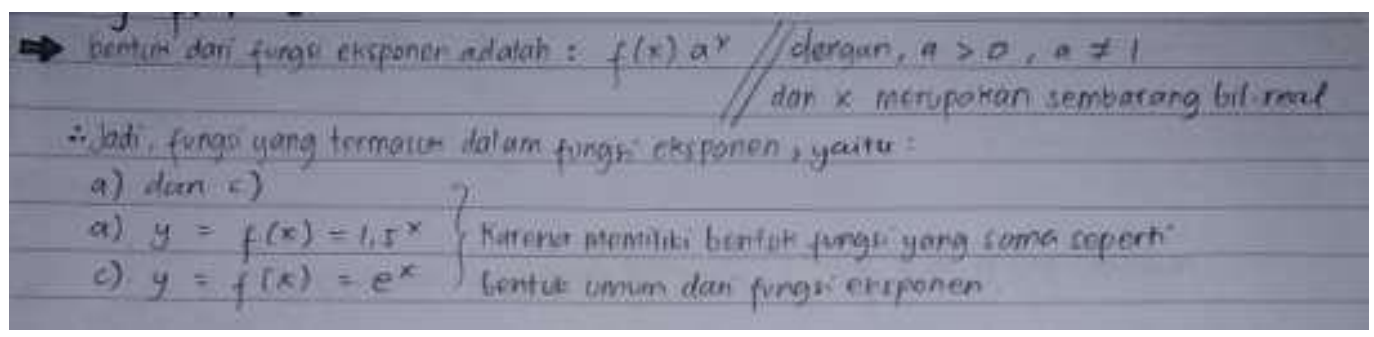

Gambar 4. Jawaban soal nomor 1 siswa X3

Dari hasil jawaban siswa di atas, siswa sudah cukup baik dalam menuangkan persoalan model matematika ke dalam bentuk argumen sendiri, hanya saja belum atau kurang mampu dalam menggambarkan 
situasi dari pertanyaan apa yang ditanyakan di dalam soal. Untuk hasil dari video penjelasan soal nomor 1 dari siswa X2 sudah cukup baik hanya saja masih belum memahami maksud dari soal tersebut. Hasil persentase skor untuk persoalan nomor 1 yaitu 50\% dan berada pada kategori sedang.

\section{Jika $x_{1}$ dan $x_{2}$ memenuhi persamaan $5^{x}-6(\sqrt{5})^{x}+5=0$, maka tentukan nilai $x_{1}$ dan $x_{2}$.}

\section{Gambar 5. Soal Nomor 5}

Pada soal nomor 5 siswa di minta untuk mencari dan menyelesaikan bentuk matematika ke dalam angka bulat atau bahasa yang lebih mudah dimengerti. Di bawah ini adalah hasil pekerjaan siswa yang masih mengalami kesalahan dalam menjawab persoalan

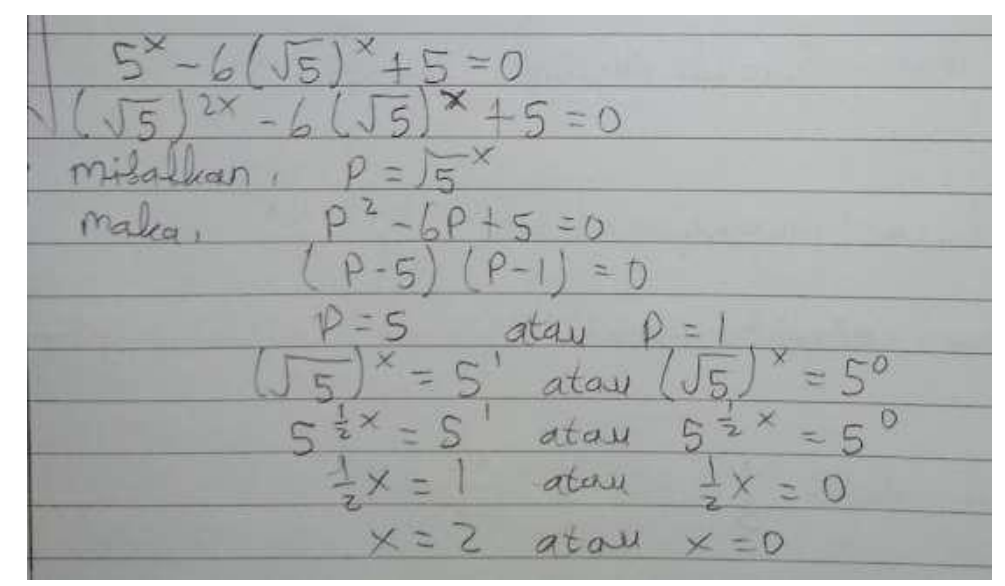

Gambar 6. Jawaban Soal Nomor 5

Dari hasil jawaban siswa di atas, siswa sudah cukup baik dalam menuangkan persoalan model matematika ke dalam konsep eksponensial yang sudah dipelajari, hanya saja belum atau kurang mampu dalam membuat kesimpulan dari hasil akhir soal tersebut. Hasil persentase skor untuk persoalan nomor 5 yaitu $25 \%$ dan berada pada kategori rendah. Untuk soal nomor 2, 3, dan 4 persentasenya termasuk ke dalam kategori tinggi dan sangat tinggi. Hal ini membuktikan bahwa siswa sudah baik dalam menyelesaikan masalah atau soal berdasarkan konsep maupun aturan matematika. Hasil penelitian ini sejalan dengan kejadian di lapangan melalui Google Classroom, dimana benar adanya siswa sudah dapat memahami konsep dari eksponensial itu sendiri meskipun belum terbilang sangat baik. Terlihat di soal pertama yang pada dasarnya menanyakan tentang definisi eksponensial justru siswa mengalami kesulitan dan kendala saat pengerjaan soal tersebut. Namun melihat hasil persentase dari penelitian di atas berdasarkan Arikunto (2009) dapat peneliti nyatakan bahwa kemampuan komunikasi matematis siswa untuk jenjang SMA Program IPA materi eksponensial sudah tergolong baik dengan interval $40 \leq P \leq 100$.

\section{SIMPULAN}

Berdasarkan hasil penelitian yang telah di uraikan, maka dapat diambil kesimpulan bahwa kemampuan komunikasi matematis pada siswa SMA Program IPA pada materi eksponensial masih termasuk kategori rendah ke tinggi. Hal ini dapat dilihat dari hasil persentase skor pada setiap butir soal dari 5 persoalan dua soal ada pada kategori sedang dan rendah serta tiga soal ada pada kategori tinggi dan sangat tinggi. Selain itu masih banyak siswa yang kesulitan dalam mengisi tes pemahaman matematis tersebut. Dimana untuk kemampuan pemahaman yang di analisis siswa masih kurang menguasai soal atau pertanyaan, rata-rata siswa sebelum mulai mengerjakan soal sudah terlebih dahulu menganggap soal terlihat sulit sehingga siswa kurang antusias dalam memahami pertanyaan dalam soal tersebut, siswa juga masih merasa bingung untuk menyelesaikan soal yang 
Jurnal Ilmiah Matematika Realistik (JI-MR), Vol: 1, No: 2, 1-7

diberikan. Sedangkan untuk kemampuan komunikasi siswa masih banyak belum memahami konsep eksponensial.

\section{REFERENSI}

Arikunto, S. (2009). Dasar-Dasar Evaluasi Pendidikan. Jakarta:Bumi Aksara

Armiati, 2009. Komunikasi Matematis dan Kecerdasan Emosional. Artikel dipresentasikan dalam Seminar Nasional Matematika dan Pendidikan Matematika Jurusan Pendidikan Matematika FMIPA UNY. ISBN: 978 979-16353-3-2. (hal. $270-280$ )

Bernard, M. (2015). Meningkatkan kemampuan komunikasi dan penalaran serta disposisi matematik siswa SMK dengan pendekatan kontekstual melalui game adobe flash cs 4.0. Infinity Journal, 4(2), 197-222.

Choridah, D. T. (2013). Peran Pembelajaran Berbasis Masalah untuk Meningkatkan Kemampuan Komunikasi dan Berpikir Kreatif serta Disposisi Matematis Siswa SMA. Jurnal Infinity, 2(2).

Chotimah, S., Bernard, M., \& Wulandari, S. M. (2018). Contextual approach using VBA Learning Media To Improve Students' Mathematical Displacement and Disposition Ability. Journal of Physics: Conference Series, 948 (1).

Dewi, P. S., \& Septa, W. H. (2019). Peningkatan Kemampuan Pemecahan Masalah Dan Disposisi Matematis Siswa Dengan Pembelajaran Berbasis Masalah. Mathema: Jurnal Pendidikan Matematika, 1(1), 31 - 39.

Hendriana, H. Rohaeti, E. E., \& Sumarmo, U. (2017). Hard Skill dan Soft Skill Matematika Siswa. Bandung: PT. Refika Aditama.

Hendriana, H., \& Soemarmo, U. (2014). Penilaian Pembelajaran Matematika. Bandung: PT. Refika Aditama.

Hujodo, H. (2003). Pengembangan Kurikulum dan Pembelajaran Matematika. Malang : Jurusan Matematika FMIPA UNM.

Maskar, S. (2018). Alternatif Penyusunan Materi Ekspresi Aljabar untuk Siswa SMP/MTs dengan Pendekatan Pendidikan Matematika Realistik. Prisma: Jurnal Pendidikan Matematika. 7(1), 53-69

Maskar, S., \& Anderha, R.R. (2019). Pembelajaran Transformasi Geometri dengan Pendekatan Motif Kain Tapis Lampung. Mathema: Jurnal Pendidikan Matematika. 1(1). 40-47.

National Council of Teacher Mathematics. (2000). Principle And Standarts For School Mathematich.USA: NCTM.

Puspaningtyas, N. P. (2019). Kemampuan Berpikir Lateral Siswa SD dalam Pembelajaran Matematika. Mathema: Jurnal Pendidikan Matematika, 1(1), 24 - 30.

Ruseffendi. (2006). Pengantar Kepada Membantu Guru Mengembangkan Kompetensinya Dalam Pengajaran Matematika. Bandung: Tarsito.

Sugiyono. (2016). Metode Penelitian Kuantitatif, Kualitatif, dan R\&D. Bandung: PT. Alfabet.

Syarifah, L. L. (2017). Analisis Kemampuan Pemahaman Matematis Pada Mata Kuliah Pembelajaran Matematika SMA II. Jurnal Pendidikan Matematika, 10(2), 57 - 71.

Ulfa, M. (2019). Strategi Preview, Question, Read, Reflect, Recite, Review (PQ4R) Pada Pemahaman Konsep Matematika. Mathema: Jurnal Pendidikan Matematika, 1(1), 48 - 55.

Vui, T. (2007). A Lesson that may Enhance Classroom Communication to Develop Student's Mathematical Thinking in Vietnam. Paper presented at APEC TSUKUBA International Conference III. 